\title{
The evolution of regional language maintenance in Southern Alsace and Northern \\ Catalonia: A longitudinal study of two regional communities \\ Judith Broadbridge and Dawn Marley
}

\section{Introduction}

This chapter will revisit two regional languages, which we first encountered in the context of our doctoral research in the late 1980s and early 1990s. The initial study of Alsatian took place in 1994, whilst two studies were conducted for Catalan, the first in 1988 and the second in 1993. This chapter represents a reassessment of the situation, almost 25 years after the introduction of the European Charter for Regional or Minority Languages, with the aim of ascertaining how this Charter has affected Alsatian and Catalan and whether the professed language loyalty and regional pride have translated into more than vague positive attitudes.

New means were sought to access our quantitative data and this was combined with a review of the linguistic landscape and an assessment of the situation in terms of ethnolinguistic vitality. Through these complementary methods we hoped to present a balanced picture of the ways in which these two language contact situations have evolved in the last quarter of a century.

Firstly, we will give a brief overview of our original research, and will note the major changes that have affected the development of regional languages in France since that time. We will then resume the general conclusions reached in our original studies, followed by an analysis of the present situation, with the aim of assessing the current ethnolinguistic vitality of each language. Our provisional conclusions will then assess the extent to which these two languages could be perceived, in Fishman's (1991) terms, as success stories for reversing language shift. 


\section{Summary of Original Research}

Our doctoral research projects were essentially quantitative studies on language use and attitudes in two areas where, historically, a regional language other than French was spoken. (For more detailed accounts of the original studies, see Broadbridge, 1998 and Marley, 1996.) We were interested in finding out how many people self-identified as speakers of the regional variety, the contexts in which they used it, and their perception of it. In both cases our methodology was based on questionnaires, but the way in which the questionnaires were administered differed. In the case of Alsatian, a telephone survey was conducted in 1994, with the interviewer calling randomly selected numbers in the village of Zillisheim in the département of Haut-Rhin, complemented by a face-to-face survey in a local lycée. In the case of Catalan, a door-to-door survey was conducted in two contrasting areas of Perpignan in 1988, the working-class area of Saint-Mathieu and the more middle-class area of La Lunette, followed by a survey in a number of selected schools in the same locations in 1993.

We analysed our data in the light of Fishman's Reversing Language Shift (1991) and assessed the 'ethnolinguistic vitality' of the languages using the criteria developed by Giles, Bourhis and Taylor (1977). Our research did not yield highly positive results, but neither did it suggest imminent language death.

Our more recent studies of these two languages are mainly based on secondary research, complemented, in the case of Alsatian, by a small-scale online questionnaire. Before looking at our findings, it will be useful to examine the changes that have affected France's regional languages over the last 25 years.

\section{Regional Languages in France}

At the time of our first studies, it was widely considered that regional languages were rapidly dying out, but that changing attitudes at European level could potentially help to reverse the 
ongoing language shift. The European Charter for Regional and Minority Languages of 1992 struck an optimistic note for minority languages. The concept of European regions was also being discussed, and indeed led to the creation, in 1994, of the European Committee of the Regions. Nevertheless, at the very same time, on 25 June 1992 to be precise, the French government demonstrated its resistance to this movement by changing the Constitution in order to reaffirm the role of French in France, inserting the words 'La langue de la République est le français' at the start of Article 2. This apparent blow to minority languages, and act of defiance towards the European Charter, would, in hindsight, seem to be symbolic, as it did not prevent the rather positive development of the legal situation of regional languages in subsequent years. Most significantly, on 23 July 2008, the Constitution was modified again, this time arguably in favour of regional languages, with the addition of the words 'Les langues régionales appartiennent au patrimoine de la France'. The Assemblée nationale proposed that these words be inserted in Article 2, and thus receive greater prominence, but the Senate rejected this and the sentence was added to article 75 . For some, this change demonstrates that France respects and recognises minority languages, and therefore does not need to ratify and implement the European Charter. For others, however, it is far from adequate.

The debate over just what this recognition could or should mean in practice for the ratification of the Charter and regional languages has continued sporadically over the last twenty years. In 2013 it started again when the Comité consultatif pour la promotion des langues régionales et de la pluralité linguistique interne presented its report to the Minister for Culture. Its aim was to redefine public policy and it recognised the importance of transborder languages, a group which includes Alsatian and Catalan. These transborder languages are important not only as carriers of regional cultural heritage and markers of regional identity, but also because they can play a role in supporting learning of related languages and improving exchanges with neighbouring countries. Alsatian in particular is perceived as an important link with Germany, 
and as an economic asset for speakers. As for Catalan, it may be considered a cultural as well as an economic asset, given the power, in these respects, of Barcelona, the capital of Spanish Catalonia.

After two years of discussion, the General Assembly of the Conseil d'Etat decided yet again, on 30 July 2015, that, on constitutional grounds, the European Charter for Regional and Minority Languages could not be ratified by France. It was concluded that approval could only occur if France were to interpret the Charter in a way that would continue to allow French to be used as sole official language. In October 2015, therefore, the Senate rejected the constitutional bill authorising ratification of the Charter.

Before looking more closely at our studies, it should be mentioned that there is another factor that has come into prominence since the early 1990s, namely the Internet and its overwhelming impact. This development has transformed lives in multiple ways, including numerous aspects of language use. This global phenomenon could be viewed as both positive and negative for minority languages, when an online presence is essential for all languages. On the negative side, the increased use of English, particularly in the early days of the Internet, was seen to have a damaging effect on all other languages. However, the percentage of Internet usage in English is decreasing, falling from an estimated $80 \%$ in the mid-1990s (Crystal nd) to $25.5 \%$ in 2017 (statista). On the positive side, many organisations and associations are able to take advantage of an Internet presence to promote their language, and a quick online search reveals that both Alsatian and Catalan have this, not least for Alsatian with the website of the Office pour la Langue et les Cultures d'Alsace et de Moselle (formerly, up until 2017, the Office pour la Langue et la Culture d'Alsace) (OLCA). As for Catalan, it occupies a unique position on the Internet, since in 2006 it was granted the right to its own domain name (.cat) despite being a minority language (Generalitat de Catalunya (nd), p.18) and is the $8^{\text {th }}$ language in the world in terms of Internet penetration, with a penetration rate of 71.44 , higher than that of French, 
Italian, German and Spanish (Generalitat de Catalunya, 2017). The vast majority of the Internet content in Catalan comes from the Spanish side of the Pyrenees, but there are also sites specifically by and for Catalan speakers in France.

\section{Alsatian}

\subsection{General Conclusions 1994}

The survey undertaken in 1994 in Zillisheim in Haut-Rhin provided an insight into the percentage of people able to communicate in Alsatian and the different domains in which they used it at that time. $64.6 \%$ of respondents spoke Alsatian 'easily' or 'moderately well'. At least some, if not many, of those questioned used Alsatian across all non-formal situations: $67.5 \%$ with grandparents, $55.3 \%$ with parents.

Although the percentage is in the 90s for formal situations, there is no area where purely French is spoken by everyone, except for the youngest age group. As far as can be ascertained, those who could speak Alsatian did in at least some contexts.

75\% expressed their liking of hearing/speaking Alsatian, whilst $81.5 \%$ believed Alsatian was helpful in finding employment

In spite of this positive perception of Alsatian, Alsatians had a tendency to refer to the regional language as le dialecte. Clearly this could simply be a direct transfer of vocabulary from Alsatian or German. Nevertheless, this does serve to underline the power struggle, with Alsatian being only a dialect as opposed to a language like French/German. Moreover, the vast majority $(91.3 \%)$ saw the future of Alsatian in a rather negative light, as they felt that fewer and fewer people were speaking Alsatian. Finally, less than half (43.5\%) supported the view that you were not a true Alsatian if you did not speak Alsatian. 


\subsection{Ethnolinguistic Vitality Today}

\subsubsection{Language Use}

According to a study carried out by edinstitut (2012) on behalf of OLCA (the then Office pour la Langue et la Culture d'Alsace) the proportion of Alsatian speakers in Southern Alsace is $38 \%$, with this percentage falling to $33 \%$ in the Mulhouse area into which Zillisheim falls. Although the figures do not relate to exact geographical like-for-like, it is still clear that there has been a considerable drop in capacity to speak the local variety. A conclusion which is reflected, too, in report $\mathrm{N}^{\circ} 4238$ on the proposed law in relation to regional languages presented to the Assemblée nationale on 22 November 2016 (assemblée-nationale, 2016), which estimates that the number of people capable of expressing themselves in Alsatian has fallen by two thirds between the generations born in 1930 and those born in 1980 and further confirms the findings of Marie-Noële Denis in 2003.

Although Denis (2003) states that the use of Alsatian remains far more widespread than for any other of France's regional varieties, according to the mini study of 20 people carried out in Zillisheim in 2015 by Broadbridge, the only situation in which the recent Zillisheim respondents claim to speak solely the regional idiom is with parents or grandparents. A mix of French and Alsatian is said to be employed in a wider range of contexts with family, friends and shop/café personnel, but only French with teachers/lecturers or administrative interaction. Even some of those claiming to speak Alsatian 'well' or 'moderately well' do not use the regional variety at all. Thus, not only is the knowledge of Alsatian on decline, but so is its dayto-day use. 
The aforementioned report $\mathrm{N}^{\circ} 4238$ also notes that the network of private and public sector bilingual schools, both offering similar educational provision, serve, today, around 80000 children (assemblée-nationale, 2016). Across all regional languages there was an increase of 24\% in teaching between 2009-10 and 2011-12 according to the report from the Comite consultatif (2013: 25). These figures may seem positive, but the percentage of pupils with a specialism in Alsatian for the brevet des collèges is just 1\% (presumably in relation to national figures, but this is not explicit in the original source) (Comité consultatif, 2013: 31).

\subsubsection{Linguistic Status}

It might be supposed that Alsatian would benefit from an enhanced linguistic status, given that it is a language which is related to the official language just across the border in a neighbouring country. In the framework convention on the Alsatian policy on multilingualism, signed on 1 June 2015 by the region, the départements, the préfecture and the Académie de Strasbourg, it is stated quite clearly that the term regional language of Alsace means German in its standard and dialectal (Alemannic and Frankish) forms (Convention cadre nd: 3). The Académie de Strasbourg underlines that German, described as the regional language and the language of the region's neighbours, is at the heart of its language policy (Académie Strasbourg a, nd). This is both an advantage and a disadvantage. For Abalain (2007: 240) this view constitutes a step towards the snuffing out and disappearance of the regional language. This opinion is shared by Penelope Gardner-Chloros, who believes that the refusal to standardise the Alsatian language indicates a desire to see it die (2013: 173).

Alsatian speakers themselves continue to refer to their language as le dialecte, a somewhat negative term, as discussed in section 3.1. It is also to be noted that the reaction of the Zillisheim respondents to the notion that you are not a true Alsatian if you do not speak Alsatian is less positive than in 1994 (only four of those questioned agreed with this proposition as against five 
who disagreed and six who did not respond). Finally, all those taking part in the study are of the opinion that fewer and fewer Alsatians speak Alsatian and do not predict a rosy future for the regional language.

\subsubsection{Institutional Support}

The Ministry of Education has undertaken a review of the teaching programme such as to reflect the European Framework of Reference for Languages. Moreover, there are school inspectors specifically for Alsatian employed in Alsace (Comité consultatif 2013: 30). However, teaching in Alsatian at pre-school develops into programmes of study of the regional languages of Alsace in primary and secondary school. These incorporate expressions in the regional variety. On the Académie de Strasbourg website it is noted that, at lycée level, a bilingual qualification is offered in the form of the Abibac, which leads to the dual award of the German Abitur and the French baccalauréat and that, currently (in 2016/17), this programme is being followed by 1424 pupils in 18 lycées, of which eight are in Haut-Rhin (Académie Strasbourg b, nd). The Abibac is matched by a professional equivalent, the Azubibac pro, initially piloted in four lycées in the Académie, with a cohort of 55 pupils, who will be gaining this qualification at the end of the 2016/17 school year (Goulet, 2017). Since September 2016, eight lycées have provided this programme of study, with five of these being in Haut-Rhin (Académie Strasbourg c, nd). Thus, educational provision seems to place heavier and heavier emphasis on German as pupils progress through the school system and appears to belie the statement in the framework convention, mentioned in the previous section (3.2.2), according to which there cannot be durable bilingualism which would refuse to recognise the importance of good dialectal practice (Convention cadre 2015: 3).

Outside education, Alsatian is supported by OLCA (previously the Office pour la Langue et la Culture d'Alsace and now the Office pour la Langue et les Cultures d'Alsace et de Moselle) 
which was founded in 1994 by the then region of Alsace and funded by the region and the two départements of Bas-Rhin and Haut-Rhin. Its declared role is to promote the vitality of the regional identity of Alsace by highlighting its heritage and linguistic and cultural specificities (OLCA a, nd).

The framework convention on the Alsatian policy on multilingualism of 1 June 2015 (see section 3.2.2) forms part of an overarching project shared by the French state, the then region of Alsace and the two départements, Bas-Rhin and Haut-Rhin, in close collaboration with OLCA and includes two operational agreements. This would clearly appear to be a positive development. However, the press release relating to this includes a statement of OLCA's mission, described as being to work towards the greater presences of Alsatian and German in every domain (Académie Strasbourg, 2015). Thus, once again, German is linked to the regional language.

In relation to the locality of Zillisheim, Mulhouse (the nearest major conurbation to Zillisheim in Haut-Rhin, as noted above) has a specific deputy mayor with allocated responsibility for Mulhouse cultural heritage and bilingualism (Mulhouse adjoints, nd)

The use of Alsatian in the legal system is not supported by the French state. French was introduced as the official language in Alsace in early 1919 (OLCA b, nd). Article 23 of the Civil Procedure Code (legifrance a, nd) states that in civil cases the magistrate is not obliged to involve an interpreter if he/she shares the language of communication of the parties involved. This relates to any linguistic variety, but obviously would include Alsatian or even German. This is not the case in criminal cases, where it is obligatory to employ an interpreter, as indicated in Article 407 of the Criminal Code (legifrance b, nd).

According to the Comité consultatif (2013: 94), 92 hours of television and 21.5 hours of radio are broadcast in Alsatian, although there is no indication of the time span in which this hourage occurs. In particular, France Bleu offers a daily news update in Frankish. This apparently 
positive situation is viewed somewhat sceptically by Pascale Erhart in her discussion on the language of television in Alsace. She believes that France 3, for example, is simply a reflection of the decline of usage of the regional varieties when it could have served as a catalyst for renewed transmission of Alsatian from one generation to another (2010).

As far as literature is concerned, Denis (2003) concludes that this is disappearing little by little and now only exists in the form of rural and militant amateur theatre. Thus, the president of the Fédération Théâtres Alsaciens, F. Schaefer (nd), underlines that the role of the Fédération is to be at the forefront of creation in Alsatian and the declared aim of the Groupement du Théâtre $d u$ Rhin (nd), is to promote amateur theatre in Alsatian and in French.

A final element to consider is the presence of Alsatian in the linguistic landscape. This relatively new aspect of sociolinguistics is seen as particularly relevant to research on minority language communities, as is illustrated in various publications in the last few years (for example, Cenoz and Gorter, 2006; Gorter et al, 2012; Blackwood and Tufi, 2015). It was taken up by, for example, Bogattoand Hélot (2010) who specifically explored shop frontages in Strasbourg. Schrijver (2006: 222) highlights that public road and street signs fall under local and regional jurisdiction and notes that, whilst the French signs remain the official format, there is no prohibition in place as regards adding bilingual versions. An examination of street name signage in Mulhouse reveals that this appears to be increasingly bilingual. As explained in July 2017 on the website dedicated to presentation of the bilingual street signs (plaquesbilingues, nd), it is expected that the $250^{\text {th }}$ sign will be unveiled in 2018 . The website further notes that this marks the steady continuation of a policy put in place in 1991 and supported by the current mayor and relevant representatives. Thus, this enhanced use of Alsatian on signage again demonstrates a positive attitude to the regional language on the part of the local state authorities. However, on a more negative note, this use of Alsatian could potentially be seen as a form of commodification, boosting a regionality which serves primarily to attract tourists 
(see Heller et al, 2014). Nevertheless, it could be argued that, if this were so, it would be expected that the signs would have appeared predominantly in touristic locations and this is not demonstrably the case.

\subsubsection{Economic Status}

Some believe that knowledge of Alsatian can help in the search for employment. Statistics would seem to support this as 63,000 (Comité consultatif 2013: 18) Alsatians work in Germany and Switzerland, and, in addition, the then region of Alsace put in place a series of schemes to support the cross-border mobility of its inhabitants.

Nevertheless, it is to be noted that requiring expertise in a particular language or dialect which is not necessary to a post is a form of indirect discrimination linked to origin (Pôle Emploi, nd). It is also somewhat disquieting that an official Pôle Emploi publication (2010: 4) on drawing up job advertisements and the law specifically cites Alsatian, under the heading Mentions interdites, as an example of a term which is forbidden.

\section{Catalan}

\subsection{General conclusions 1988/1993}

The two separate surveys on Catalan, the door to door survey in two districts in 1988 and the follow-up survey conducted via schools in the areas in 1993, gave rise to differing responses, partly due to the different methods of data collection, and possibly as a result of changing attitudes towards regional languages in the intervening five years.

Informants were asked if they could speak Catalan or if they spoke it 'a little or with some difficulty'. In 1988, 54.4\% of informants claimed to speak Catalan, compared to $39.6 \%$ in 1993. On the other hand, in 1993 a higher number of informants claimed to speak it 'a little' 
or with some difficulty'. Moreover, there was also a general tendency for younger informants to claim that they spoke the language.

In terms of attitudes towards Catalan, a clear majority of speakers stated that they liked speaking Catalan (69.4\% in 1988 and $79.2 \%$ in 1993). An overwhelming majority of all informants (including those who did not identify themselves as Catalan speakers) approved the idea that Catalan should be maintained in the Perpignan region $(80.7 \%$ in 1988 , and $72.6 \%$ in 1993). Moreover, among Catalan speakers, 61.6\% in 1988 and 66.3\% in 1993 believed it was important to speak Catalan. On a rather less positive note, the primary reason for speaking Catalan suggested was 'for traditions/ culture' (34.5\% in 1988 and 26.2\% in 1993), which would seem to imply that it was not considered relevant to modern interaction. The overall picture, then, is of a declining number of speakers, but a generally sympathetic attitude towards the language.

\subsection{Ethnolinguistic vitality today}

\subsubsection{Language Use}

The most recent study of use of Catalan indicates that $35.5 \%$ of the population of Northern Catalonia claims to speak Catalan, and $61 \%$ to understand it (Eurodistrict de 1'Espace Catalan Transfrontalier, 2015). According to the 2013 Comité consultatif report (apparently based on the 1999 French census figures) Catalan had 170,000 speakers, of whom 80,000 regularly used the language (Comité consultatif, 2013: 11). Thus Catalan would seem to be one of the most spoken regional languages in France. The report also notes there are some 13,000 school pupils learning Catalan (Comité consultatif, 2013: 25). This figure is also one of the highest nationally, although it is a long way behind Alsatian.

Nevertheless, the report highlights that these figures will not ensure the survival of the language. It quotes a Catalan language organisation, Association pour l'enseignement du 
catalan, as saying that bilingual education is not sufficient to counter the demographic impact of the loss both of older speakers and of intergenerational language transmission within the family. That organisation estimated that, annually, around 3000 Catalan speakers die in the Pyrénées-Orientales, whilst only around 300 are completing a bilingual education (Comité consultatif, 2013: 13). Moreover, the 2015 study makes clear that, although numbers claiming the ability to speak Catalan remain stable, numbers actually using the language regularly are tiny: only $12.7 \%$ of the sample, mainly older informants, claimed Catalan as their first language, and only $5.7 \%$ affirmed that Catalan was their 'habitual language'. This report suggests that intergenerational transmission is very weak: $0.7 \%$ of parents speak Catalan to their children (Eurodistrict de 1'Espace Catalan Transfrontalier, 2015). Baylac Ferrer (2017, personal communication) suggested that the practice may be limited to a few hundred, maybe thousands, of families like his own, but that there is indirect transmission taking place, whereby children are not directly addressed in Catalan, but hear the language around them, among older family members, throughout their lives.

Although the 2015 report does not suggest a significant upturn in speaker numbers, neither does it suggest further decline. Interestingly, it also finds that $46.2 \%$ of informants believed Catalan was quite widely used, whilst only a quarter thought it was hardly ever or never used, indicating a feeling that the language has a real presence. Moreover, $70 \%$ of informants said they were in favour of bilingualism outside the home, and $58 \%$ were even in favour of Catalan having co-official status (Eurodistrict de l'Espace Catalan Transfrontalier, 2015). Despite these positive opinions, Baylac Ferrer (2012) has noted that autoodi (self-hatred) still impacts negatively on potential users of Catalan, given the centuries of diglossia in favour of French. 


\subsubsection{Linguistic status}

Catalan's status is quite unique in Europe. Whilst a minority language, Catalan is also the ninth largest language in Europe, in terms of speaker numbers (Generalitat de Catalunya, nd: 23); moreover, it is the sole official language in Andorra, and a co-official language in Spain. This results in a cross-border situation similar to that of Alsatian, as highlighted above (3.2.2), where Alsatian is regarded as a dialectal form of German, a high status national language. For Catalan, as for Alsatian, this situation can be seen as both an advantage and a disadvantage. On one hand the official status of Catalan in Andorra and Spain shows that Catalan is a language on a par with French; the fact that it is the language of government and the State, of education and the media in a prosperous region and in a big city as dynamic as Barcelona may be viewed as a source of pride. On the other hand, these very factors may serve as 'proof' that the Catalan of Northern Catalonia is not a language at the same level, particularly if they struggle to understand the varieties across the border.

Catalan undoubtedly enjoys an enhanced status in Perpignan, where the language is closely associated with local identity. Baylac Ferrer (2010) notes that what he terms an Irish-style linguistic identification can be observed in the area: Catalan is recognised as the historical language of the region, and is an integral part of local cultural identity, yet very few people feel the need to actually speak the language.

This sense of linguistic identity is most obvious in sport, especially rugby. Perpignan is home to two rugby teams: Union Sportive des Arlequins Perpignanais (USAP) for rugby union, and the Dragons catalans for rugby league. Baylac Ferrer (2010) speaks of 'catalanisation' via rugby, and Lagarde (2013, p.462) refers to a fanatical Catalan identity fabricated and exploited by sports clubs. On the USAP website, Catalan is used emblematically in terms such as 'els amics' ('friends' of the club) and 'els nins' (young supporters), whilst the anthem of the 
Dragons team is 'Els segadors', also the national anthem of Catalonia (Dragons Catalans, 2017).

These claims to a Catalan identity do not mean that rugby fans discuss the matches in Catalan, but rather that the language enjoys a degree of respect and affection in the collective imagination. A very small minority of supporters would be capable of speaking Catalan, yet a majority claim this language as the symbol of their team and of their local identity. As Lagarde (2013: 461) notes, there is a considerable gulf between linguistic competence and selfidentification with the language. According to his research, those individuals with the lowest levels of linguistic competence in Catalan are the most likely to place a high symbolic value on the language.

\subsubsection{Institutional Support}

Catalan fares somewhat better than many other regional languages in terms of institutional support, in large part thanks to the support from Southern Catalonia, but also because the relative similarity of the language on both sides of the Pyrenees means that Catalan speakers and learners in France can take advantage of educational, cultural and commercial opportunities from Spanish Catalonia. It is also worth noting that since 2007 there is a transborder 'Eurodistrict', the Espace Catalan Transfrontalier, which allows the local governments on either side to work together on projects, including cultural and linguistic.

The influence from south of the border has been partly responsible for the recent positive development in education. According to Sanchiz and Bonet (2009) learning Catalan, and accessing Catalan culture, is, today, clearly seen as a 'plus' and there is a growing demand for Catalan language classes. They claim that the real problem is the lack of teachers, and the overloaded school timetable. 
A range of institutions exists to meet the demand for Catalan teaching. At primary school level, there is a network of private schools (Bressola), and two immersion schools in the public sector (Arrels). The existence of the latter is highly unusual in France, and has only come about in the last few years, as a result of the Arrels association working together with the local authorities. The opening of the second Arrels school in 2015 was in response to growing demand following the success of the first school, opened in 2014 (La Clau, 2015).

Elsewhere in the public sector there are bilingual classes at every level, and around a quarter of all pupils at primary school are in a bilingual stream. Sanchiz and Bonet (2009) note, however, that there is a sharp fall in take-up of bilingual classes at the start of secondary school, since many parents consider that their children are bilingual at this point and would do better to start learning foreign languages.

There is also provision in higher education: at the University of Perpignan, Catalan is offered at undergraduate and postgraduate levels. In addition, due to its status as co-official language in Spain, Catalan can be studied as a foreign language at several other universities across France, and there is a French association of Catalan specialists, which brings together researchers and encourages research and teaching in all areas of Catalan culture.

Finally, this review of education would be incomplete without mention of the Université Catalane d'Été. This summer school was created in 1968 in Prades, a small town in the Pyrenees, as a means of promoting and advancing Catalan language and culture, and has continued every year, attracting around 1500 people in recent years.

Beyond education, Catalan enjoys official support from the mairie (town council) and conseil général (regional council). The official website of the mairie identifies the town as 'Perpinyà la catalana/ Perpignan la catalane', whilst the website of the department of PyrénéesOrientales identifies the department as 'L'accent catalan de la république française'. Both 
bodies have gone beyond this symbolic reference to the language, and have produced charters on local linguistic policy, which are very favourable towards Catalan.

Despite assurances of goodwill towards the Catalan language, its use in the legal system is not supported by the French state, and these two charters also state clearly that the promotion of Catalan is not at the expense of French, and does not call into question the official character of the French language.

In terms of media support, Catalan was already relatively well represented at the time of our first study: the Catalan press from Spain was readily available, and satellite television allowed people to watch Catalan channels broadcasting from Barcelona. Radio Arrels, an independent station based in Perpignan, had been broadcasting exclusively in Catalan since 1981. A generation later a far wider range of Catalan channels from Spain is available, and there is now regular Catalan broadcasting on French channels, in particular France 3 Sud, France Bleu Roussillon and TV3.

In terms of cultural production, Northern Catalonia benefits from the flourishing Catalan literary scene south of the Pyrenees. However, the region is not completely dependent on Spain for its cultural production, as other forms are home-grown, most notably music and dance, such as the sardana. There are also numerous cultural associations in Northern Catalonia, and a strong sense of pride around 'Catalan' traditions such as the Procession of the 'Sanch' on Good Friday.

A final point to consider is the presence of Catalan in the linguistic landscape. Although no attempt was made to analyse the linguistic landscape of Perpignan in the original study, it is probably fair to say that this has undergone significant change. As noted earlier, Perpignan town council clearly identifies the town as 'la catalane' and seems to use Catalan systematically in public signage. This practice, according to Blackwood and Tufi (2016: 96), 'anchors Perpignan within a Catalan cultural sphere in a way not replicated in other parts of France'. 
Blackwood and Tufi (2016: 98) find it noteworthy that French local government is responsible for placing Catalan in the linguistic landscape. (Although see above in relation to Alsace.) Certainly, it represents a change of direction after centuries of suppression. This move towards widespread bilingual signage can be interpreted as an acceptance on the part of the French state that Catalan is a language which plays an important role in the identity of the town and the region. On the other hand, as in Alsace, this use of Catalan could be seen as a form of commodification, giving the town an exotic edge that makes it more attractive to tourists (see Heller et al, 2014).

\section{Conclusions}

A quarter of a century on, it seems that 'plus ça change...'. The world has changed, quite dramatically in many ways, and some of these changes have had unexpected and profound consequences on language use and attitudes in France. Nevertheless, our conclusions remain somewhat ambivalent.

Alsatian's linguistic relationship with German, the/an official language in neighbouring countries, is not necessarily an unmitigated blessing, with bilingual education seeming to favour standard German and this impinges on opportunities for learning the regional language. However, overall, there is clearly a higher level of institutional support than there was in the early 1990s.

The informants in Zillisheim and the overarching situation in Haut-Rhin and Alsace as a whole demonstrate a positive attitude towards the local language, but this attitude does not correspond to the level of language competence or use, both of which are still in decline.

Unlike Alsatian, Catalan, is in a beneficial situation with regards to it cross-border presence. It is in a special situation in Europe, given that Catalan itself is an official language elsewhere, and that it has been a genuine RLS success story south of the border in Spain. The existence 
since 2007 of a transborder 'Eurodistrict', encouraging and funding cross-border collaborations of various kinds serves to support Catalan, as do the ample opportunities for language-learning. A further positive (in this instance, shared with Alsatian) is the overt support of the language from local government.

Unfortunately, as in Alsace, the latest study of language use in relation to Catalan does not provide evidence of intergenerational transmission, and it continues to look as if the Catalans of France are choosing to be 'Catalans via French'. Although the regional language is held in high esteem this does not result in a higher level of linguistic competence/usage.

In general, Alsatian would appear to be in a more negative position in relation to its 'ethnolinguistic vitality' than Catalan. Nonetheless, the future for Catalan is not entirely optimistic and it is to be hoped that recent initiatives, highlighted in this chapter, will have a positive impact on future developments.

\section{References}

Abalain, H. (2007) Le français et les langues historiques de la France, Paris: Jean-Paul Gisserot

Académie Strasbourg a (nd) https://www.ac-strasbourg.fr/academie/politiqueseducatives/politique-des-langues/ Accessed 10.03.2017

Académie Strasbourg b (nd) https://www.ac-strasbourg.fr/publics/toutes-lesactualites/actualite/article/cooperation-avec-le-bade-wurtemberg/ Accessed 10.03.2017

Académie Strasbourg c (nd) https://www.ac-strasbourg.fr/publics/toutes-lesactualites/actualite/article/cooperation-avec-le-bade-wurtemberg/ Accessed 17.03.2017 Académie Strasbourg (2015) Un engagement collectif fort pour promouvoir l'identité, la langue et la culture régionales https://www.ac- 
strasbourg.fr/fileadmin/publ/actusportail/convention_bilinguisme/06_15_CPresse_signature_ conventions_bilinguisme.pdf Accessed 10.03.2017

assemblée-nationale (2016) http://www2.assemblee-

nationale.fr/documents/notice/14/rapports/r4238/(index)/rapports Accessed 22.02.2017

Association française des catalanistes (2016) http://france-catalaniste.com/ Accessed 13.03.2016

Azubi Bacpro (nd)

https://www.acstrasbourg.fr/fileadmin/publ/Orientation/Publication/Plaquette_azubi_bac_pr o_2016.pdf Accessed 10.03.2017

Baylac Ferrer, A. (2010) Société, langue et enseignement du catalan en Catologne Nord, résumé en français de thèse de doctorat. http://ouvrages.maison-payscatalans.eu/catalunya_nord/ala_baylac/Baylacvol3resumfrances.pdf Accessed 22.09.2015 Baylac Ferrer, A. (2012) Sociolinguistique et enseignement en Catalogne Nord, Langues et Cité no. 21, Le catalan. Délégation générale à la langue française et aux langues de France. Baylac-Ferrer (2017) email communication to D. Marley.

Blackwood, R. and S. Tufi (2015) The Linguistic Landscape of the Mediterranean: French and Italian Coastal Cities, Basingstoke: Palgrave Macmillan.

Bogatto F. \& Hélot C. (2010) Linguistic Landscape and Language Diversity in Strasbourg: The «Quartier Gare » in Shohamy E., Ben-Rafael E. \& Barni M. (Eds.) Linguistic Landscape in The City. Bristol: Multilingual Matters, pp. 275-291.

Broadbridge, J. (1998) Attitude to Alsatian as an Expression of Alsatianness, in Marley, D., M.-M. Hintze and G. Parker (eds), Linguistic Identities and Policies in France and the Frenchspeaking World, London: AFLS/ CILT, pp.87-102. 
Casa dels països catalans (2014) Bref historique de l'Université Catalane d'Été. http://www.maison-pays-catalans.eu/presentation/les-entites/entites-hebergees/uce-

universite-catalane-dete/bref-historique-de-luniversite-catalane-dete/ Accessed 13.03.2016

Cenoz, J. \& Gorter, D. (2006) Linguistic landscape and minority languages. The International Journal of Multilingualism 3, pp.67-80.

Charte en faveur du catalan (2010) http://www.ledepartement66.fr/202-charte-en-faveur-ducatalan.htm Accessed 05.04.2016

Comité consultatif (2013) Rapport du Comité consultatif pour la promotion des langues régionales et de la pluralité linguistique interne http://www.culturecommunication.gouv.fr/Politiques-ministerielles/Langue-francaise-etlangues-de-France/Politiques-de-la-langue/Langues-de-France/Langues-regionales/Rapportdu-Comite-consultatif-pour-la-promotion-des-langues-regionales-et-de-la-pluralitelinguistique-interne-2013 Accessed 22.09.2015

www.conseil-etat.fr http://www.conseil-etat.fr/Decisions-AvisPublications/Avis/Selection-des-avis-faisant-l-objet-d-une-communicationparticuliere/Ratification-de-la-Charte-europeenne-des-langues-regionales-ou-minoritaires Accessed 18.08.2015

Convention cadre (2015) https://www.acstrasbourg.fr/fileadmin/acad/Politiques/Politique_des_langues/Convention_cadre_20152030.pdf Accessed 10.03.2017

Crystal, D (nd) The Internet: A Linguistic Revolution http://www.paricenter.com/library/papers/crystal01.php Accessed 29.08.2017 Culture Communication (2013) Redéfinir une politique publique en faveur des langues régionales et de la pluralité linguistique interne. http://www.culturecommunication.gouv.fr/Ressources/Rapports/Redefinir-une-politique- 
publique-en-faveur-des-langues-regionales-et-de-la-pluralite-linguistique-interne Accessed 18.08.2015

Denis, M-N (2003) Le dialecte alsacien : état des lieux, Ethnologie française 3/2003 (Vol 33), p363-371 www.cairn.info/revue-ethnologie-francaise-2003-3-page-363.htm Accessed 26.02.2016

Dragons Catalans (2017) HYMNE ELS SEGADORS. http://www.catalansdragons.com/articles-133/135-4194-hymne-els-segadors/ Accessed 13.03.2017

edinstitut (2012) Etude sur le dialecte alsacien pour l'Office pour la Langue et la Culture d'Alsace, www.olcalsace.org (résultats détaillés sur demande auprès de l' OLCA)

Erhart, P (2010) «Les langues de la télévision régionale alsacienne », Revue d'Alsace, Vol 136 http://alsace.revues.org/205 Accessed 26.02.2016

Eurodistrict de l'Espace Catalan Transfrontalier (2015) Connaissance et emploi des langues en Catalogne Nord 2015. http://www.eurodistricte.cat/fr/documentation/connaissance-et-emploides-langues-en-catalogne-nord-2015 Accessed 16.01.2017.

European Committee of the Regions (nd) Key facts http://cor.europa.eu/en/about/Pages/keyfacts.aspx Accessed 13.01.17

Gardner-Chloros, P (2013) Strasbourg revisited: c'est chic de parler français, International Journal of the Sociology of Language. Volume 2013, Issue 224, pp.143-177

Generalitat de Catalunya (nd) Le catalan, une langue d'Europe. http://llengua.gencat.cat/permalink/7c4156d2-5385-11e4-8f3f-000c29cdf219 Accessed 05.04 .2016

Generalitat de Catalunya (2017) Ten reasons for digital products to speak Catalan. http://llengua.gencat.cat/web/.content/documents/publicacions/altres/arxius/10_raons_ang.pdf Accessed 04.08.2017 
Gorter, D., Marten, H. F., Mensel, L. Van (Eds.) (2012) Minority Languages in the Linguistic Landscape, Basingstoke: Palgrave Macmillan.

Goulet V. (2017) Les promesses de l'Azubi-Bacpro http://www.elsassjournal.com/lespromesses-de-lazubi-bacpro/ Accessed 10.03.2017

Groupement du Théâtre du Rhin (nd) http://www.theatredurhin.net/ Accessed 14.03.2016 Heller, M., J. Pujolar, A. Duchêne (2014) Linguistic commodification in tourism, Journal of Sociolinguistics 18/4, pp.539-566.

La Clau (2015) Perpignan: une 2ème école catalane Arrels à la rentrée 2015 https://www.laclau.net/info/perpignan-une-2eme-ecole-catalane-arrels-a-la-rentree-2015-10454 Accessed 05.09 .2017

Lagarde, Christian (2013) Le catalan, in Kremnitz, Georg (dir), Histoire sociale des langues de France, Rennes: Presses Universitaires de Rennes.

Le Catalan, Langues et cite no. 21, novembre 2012. legifrance a (nd) https://www.legifrance.gouv.fr/affichCodeArticle.do?idArticle=LEGIARTI000006410116\& cidTexte=LEGITEXT000006070716\&dateTexte=20170220 Accessed 20.02.2017 legifrance $b(n d)$ https://www.legifrance.gouv.fr/affichCodeArticle.do?cidTexte=LEGITEXT000006071154\& idArticle=LEGIARTI000006576502 $\&$ dateTexte $=\&$ categorieLien=cid Accessed 20.02.2017 Marley, D. (1996) Parler Catalan à Perpignan, Paris: L'Harmattan.

Ministère de l'Education (2013) Apprendre et enseigner les langues et les cultures régionales dans l'École de la République, http://www.education.gouv.fr/cid76555/une-brochure-sur-1apprentissage-et-l-enseignement-des-langues-et-des-cultures-regionales.html Accessed 19.08.2015 Mulhouse adjoints (nd) http://www.mulhouse.fr/fr/adjoints/ Accessed 21.02.2017 
OLCA a (nd) https://www.olcalsace.org/fr/l-olca-c-est-quoi/missions-et-activites Accessed 18.08.2015

OLCA b (nd) https://www.olcalsace.org/fr/observer-et-veiller/statut-de-la-langue Accessed 17.03.2017

Perpignan, le site officiel de la mairie (nd) http://www.mairie-perpignan.fr/fr Accessed 23.03.2016

plaques bilingues (nd) http://plaquesbilingues.fr/Accessed 29.08.2017

Pôle Emploi (2010) La rédaction des offres d'emploi : le cadre juridique, Guide pratique pour la rédaction des offres d'emploi, Département Internet / Direction de la Réglementation. http://www.pole-

emploi.fr/file/mmlelement/pj/df/9b/1b/89/guidepratiquedeloffrevfinale69493.pdf Accessed 29.08.2017

Pôle Emploi (nd) http://www1.pole-

emploi.fr/faq/faqemployeur?question=243\&rubrique $=47 \&$ soustheme $=5099 \&$ theme $=5094 \# 2$ 43 Accessed 19.08.2015

Pyrénées-Orientales (nd) Charte en faveur du catalan http://www.ledepartement66.fr/202charte-en-faveur-du-catalan.htm Accessed 23.03.2016

Sanchiz, M. et L. Bonet (2010) «L'enseignement du catalan en tant que langue régionale en France - État des lieux 2009 », Tréma [En ligne], 31 | 2009, mis en ligne le 24 février 2010. http://trema.revues.org/956 Accessed 13.03.2016

Schaeffer, F (nd) Le mot du Président http://federation-theatres-alsaciens.fr/?page_id=2 Accessed 14.03.2016

Statista (2017) https://www.statista.com/statistics/262946/share-of-the-most-commonlanguages-on-the-internet/ Accessed 29.08.2017

USAP (2016) http://fr.usap.fr/accueil Accessed 13.03.2016 